\title{
Ontogeny of a symbiont-produced chemical defense in Bugula neritina (Bryozoa)
}

\author{
Nicole B. Lopanik ${ }^{1,3, *}$, Nancy M. Targett ${ }^{1}$, Niels Lindquist ${ }^{2}$ \\ ${ }^{1}$ University of Delaware, Graduate College of Marine Studies, 700 Pilottown Road, Lewes, Delaware 19958, USA \\ ${ }^{2}$ University of North Carolina at Chapel Hill, Institute of Marine Sciences, 3431 Arendell Street, Morehead City, \\ North Carolina 28557, USA \\ ${ }^{3}$ Present address: University of Michigan, Life Sciences Institute, 210 Washtenaw Avenue, Ann Arbor, \\ Michigan 48109-2216, USA
}

\begin{abstract}
The larvae of the arborescent bryozoan Bugula neritina are chemically defended against predators by unpalatable secondary metabolites called bryostatins. Bryostatins, polyketidederived secondary compounds, are produced by the bacterial symbiont 'Candidatus Endobugula sertula', which is present throughout all life stages of $B$. neritina. Crude extracts of larval and all juvenile stages of $B$. neritina significantly reduced pinfish feeding $(\mathrm{p}<0.003)$. Extract unpalatability is due to high bryostatin concentrations. As $B$. neritina increases in age after larval settlement and metamorphosis, palatability increases as bryostatin concentrations decrease precipitously. Extracts of brooding portions of adult colonies reduced pinfish feeding by a significant $54 \%(\mathrm{p}=0.008)$, whereas extracts of non-brooding portions of the same colonies resulted in a non-significant $20 \%$ decline in feeding $(p=0.125)$. Our data suggest that the different life stages of $B$. neritina employ alternate defensive strategies. The mobile, short-lived larvae and early-stage juveniles are defended from predators by having deterrent levels of bryostatins; in contrast, the older juveniles and adults, which are clonal and relatively long-lived, may be defended largely by high levels of structural material (i.e. chitin and carbonate). Predation pressure on the vulnerable larval stage of $B$. neritina appears in part to have driven selection for the development and maintenance of the symbiotic relationship between $B$. neritina and $\mathrm{Ca}$. Endobugula sertula whereby the larvae are chemically defended by symbiontproduced bryostatins.
\end{abstract}

KEY WORDS: Chemical defense $\cdot$ Symbiosis $\cdot$ Bugula neritina $\cdot$ Bryostatins $\cdot$ Ontogenetic defense Resale or republication not permitted without written consent of the publisher

\section{INTRODUCTION}

In the marine environment, secondary metabolites mediate interactions between competitors, predators and prey, and hosts and pathogens (Pawlik 1993, Hay 1996, Amsler et al. 2001, McClintock \& Baker 2001, Engel et al. 2002). The importance of chemical defense has been well documented for the adult stages of many sessile clonal marine invertebrates such as sponges, soft corals, hydroids, bryozoans, and tunicates that cannot escape predators and often lack adequate physical means to routinely deter predators. However, much less is known about how other life stages of these animals defend themselves against predators. The majority of these organisms have complex life histories with a mobile larval stage, but sessile juvenile and adult stages. The mobility, morphological and size disparities between larval, juvenile and adult forms means they likely face different suites of selective forces, including predators; thus, each may employ alternative defensive strategies.

Like adults, larval stages of diverse sessile clonal invertebrates are also chemically defended (reviewed by Lindquist 2002), and for large apparent larvae that do not behaviorally avoid predators and that have no morphological features to deter them, possessing unpalatable secondary metabolites probably represents the only viable strategy for deterring predators 
(Lindquist 2002). Chemical defenses in both adult and larval stages have been documented in some sponges (Lindquist \& Hay 1996, Uriz et al. 1996), tunicates (Lindquist et al. 1992, Tarjuelo et al. 2002), a soft coral (Harvell et al. 1996), and a bryozoan (Lindquist \& Hay 1996). In certain cases, the adult is more chemically deterrent than the larvae (e.g. the sponge Crambe crambe; Uriz et al. 1996) suggesting that defensive metabolite production occurs in adult tissues. In other instances, the early stages are more deterrent [e.g. the sponges Dysidea avara (Uriz et al. 1996) and Callyspongia vaginalis (Lindquist \& Hay 1996); the gorgonian Briareum asbestinum (Harvell et al. 1996)], indicating that the immature forms may be capable of de novo production. Among sessile marine invertebrates that produce chemically defended larvae, most produce relatively few but large and conspicuous larvae. Although larval mortality can be very high (reviewed in Young \& Chia 1987), when a chemically defended larva is attacked, it is typically rejected with very little damage as evidenced by the high post-rejection rates of settlement and metamorphosis (Young \& Bingham 1987, Lindquist 1996, Lindquist \& Hay 1996). Thus, with larval mortality likely being very low for many chemically defended species, population bottlenecks should occur at other life stages (Davis 1989), probably at the early juvenile stages (reviewed by Gosselin \& Qian 1997). Lindquist \& Hay (1996) hypothesized that the chemical defense of larvae allow for the evolution of large larvae, which subsequently become larger juveniles that have higher rates of survival than smaller juveniles. Further, daytime spawning of highly conspicuous larvae, which is extremely risky for unprotected larvae, allows chemically defended larvae of sessile invertebrates in shallow waters to use strong photic cues at settlement to locate protective refuges from large mobile consumers and solar UV exposure.

The importance of chemical defenses after larval settlement and before the transition to the adult stage has not been well studied. Juvenile mortality can be very high for many benthic marine invertebrates (reviewed in Gosselin \& Qian 1997) because juveniles may not have the chemical or morphological defenses of their adult counterparts, or in the case of colonial invertebrates, grown large enough so that partial predation is not catastrophic (Jackson 1985). The presence of a chemical defense in the juvenile stages could be advantageous; however, it has been hypothesized that during development, the rapidly growing larval tissues may be sensitive to potentially toxic defensive compounds, and that production may be halted until these changes are complete (Harvell et al. 1996, Cowart et al. 2000). This does not seem to be the case for certain unpalatable echinoderm juveniles (Iyengar \& Harvell
2001), indicating that for some organisms the benefit of having the chemical defense is greater than the reduction in growth or fitness that may occur with effective concentrations of noxious chemicals.

Larvae of the arborescent bryozoan Bugula neritina are distasteful to both vertebrate and invertebrate predators (Lindquist 1996, Lindquist \& Hay 1996, Tamburri \& Zimmer-Faust 1996), and Lindquist \& Hay (1996) reported that the larval extract deters fish feeding. Recent research has demonstrated that $B$. neritina larvae are chemically defended by high concentrations of bryostatins (Lopanik et al. 2004a), which are complex cyclic polyketides (Pettit 1996, Lopanik et al. 2004b). Conversely, the extract of adult $B$. neritina is palatable to fish (Lindquist \& Hay 1996, Lopanik et al. 2004a) and contains low concentrations of bryostatins (Lopanik et al. 2004a). The disparities in deterrence and bryostatin concentrations between adult and larval tissues suggest ontogenetic differences in the production of the bryostatins, which is further complicated by the fact that a microbial symbiont of $B$. neritina, 'Candidatus Endobugula sertula', appears to be the source of the bryostatins (Davidson et al. 2001, Lopanik et al. 2004a). Although increasing numbers of secondary metabolites isolated from marine invertebrates are being shown to be produced by associated bacteria (reviewed in Kobayashi \& Ishibishi 1993, Piel 2004), ecological roles for these compounds are rarely reported. In addition to bacteria-produced bryostatins protecting $B$. neritina larvae from predators (Lopanik et al. 2004a), Gil-Turnes et al. (1989) and Gil-Turnes \& Fenical (1992) demonstrated that some symbiont-produced compounds are allelopathic to host pathogens, and Lindquist et al. (2005) described unique symbioses between marine isopods and episymbiotic microbial communities that protect the isopods from predation by fishes.

For Bugula neritina, Candidatus Endobugula sertula is present in both the larval and adult stages (Woollacott \& Zimmer 1975, Woollacott 1981). In the larvae, Ca. Endobugula sertula resides in the pallial sinus, a circular groove located at the top of the larva (Woollacott 1981, Haygood \& Davidson 1997). While it has not been unequivocally demonstrated that $C a$. Endobugula sertula inhabits the funicular cord in the adult (which connects the zooids and plays a role in the transport of nutrients within the colony), microscopy studies have shown the presence of rod-shaped bacteria morphologically similar to Ca. Endobugula sertula in the funicular cords (Woollacott \& Zimmer 1975), and PCR amplification of 16S rDNA with primers specific for $\mathrm{Ca}$. Endobugula sertula of adult tissue support the presence of $C a$. Endobugula sertula in the adult stage (Davidson et al. 2001). Ca. Endobugula sertula has not been found in seawater (Haygood et al. 1999), thus 
transmission between generations appears to be entirely vertical via larval transmission, implying that Ca. Endobugula sertula is an important ally of B. neritina with its production of deterrent bryostatins (Davidson et al. 2001, Lopanik et al. 2004a). While being demonstrably important for the larvae but not the adults, the role of the bryostatins in the ecology of early post-settlement (PS) stages of $B$. neritina is not known. Because of the inherent morphological and mobility differences between adults and larvae, they likely face different suites of predators, and consequently, they may employ alternative defenses against their predators, including structural defenses or low nutritional quality (Duffy \& Paul 1992, reviewed in Cronin 2001). Additionally, the issue of whether the bryostatins persist during the first days of growth after settlement and metamorphosis, or if bryostatin concentrations change rapidly after settlement has yet to be established. In this study, we examine the relationship between palatability and levels of bryostatins, protein, and structural material in the larval, juvenile and adult $B$. neritina to determine if these different ontogenetic stages utilize alternative defensive strategies.

\section{MATERIALS AND METHODS}

Study organisms. Colonies of adult Bugula neritina, which grow abundantly in the subtidal regions of Radio Island Jetty in Morehead City, North Carolina, USA (Hay \& Sutherland 1988), were collected by SCUBA in the spring and fall of 2001 and 2002, during the biannual peak of its reproductive output (MCDougall 1943). Colonies were maintained in flowing seawater tables at the University of North Carolina at Chapel Hill's Institute of Marine Sciences in Morehead City, North Carolina. The pinfish Lagodon rhomboides, which is abundant in coastal North Carolina (Adams 1976) and is an omnivorous predator that plays a role in the structuring of benthic communities (Nelson 1979, Heck et al. 2000), was used as a model predator for all palatability assays. Juvenile $L$. rhomboides potentially prey on $B$. neritina larvae and juveniles, as the fish inhabit the same area during the bryozoan's reproductive seasons, and are known to prey on planktonic organisms (Darcy 1985). Adult L. rhomboides is a potential predator on adult B. neritina, as it is plentiful throughout coastal North Carolina, and preys on a variety of sessile and benthic organisms that co-occur with $B$. neritina, including hydroids, tunicates, amphipods, and algae (Hay \& Sutherland 1988).

Bugula neritina life history-stage palatability and bryostatin concentration. Larvae were spawned from Bugula neritina by placing adult colonies that had been kept under a dark cover in 4 l glass jars filled with seawater and exposing them to bright light between 08:00 and 11:00 h. Adult colonies released larvae 30 to 90 min after exposure to the light. Virtually all of the spawned larvae swam to the top of the jar where they were collected by pipette and placed into ice-chilled seawater. This treatment caused them to stop swimming and to sink to the bottom of the collection vial. Larvae were pooled and divided into 3 small vials with volumetric markings. Larvae were compacted by centrifugation at low speed $(\sim 400 \mathrm{~g})$, the excess seawater removed from the vial and the larval volume measured. Methanol was added to the vial to preserve the larvae, which were then stored at $-20^{\circ} \mathrm{C}$. To collect the juvenile stages, larvae were pipeted into small polystyrene petri plates, and typically settled and metamorphosed within $2 \mathrm{~h}$ of being placed in the dishes. After the larvae settled, the plates were placed in flowing filtered seawater for the first $24 \mathrm{~h}$. The settlement dishes with the juveniles were then suspended vertically in wave tanks with flowing unfiltered seawater until they were collected at specified intervals for assays. The juveniles were removed from the settlement dishes by scraping them off the surface of the dish with a metal spatula and placed into ice-chilled seawater. The mixed sample was partitioned into 3 volumetric vials, and preserved in methanol at $-20^{\circ} \mathrm{C}$ until extraction.

Three adult Bugula neritina colonies were separated into ovicell-bearing and ovicell-free branches $(\sim 10$ to 15 branches), which differed only by the presence or absence of ovicells, calcareous brood chambers present in reproductive portions of the colony. Some of the ovicells on the ovicell-bearing branches were empty, and there were some ovicell-free zooids $(\sim 10 \%)$ on these branches. Portions of the ovicell-bearing and ovicell-free branches of these 3 adults were used to assess palatability and bryostatin concentrations among the 3 colonies, as well as to compare intracolony variability in palatability and bryostatin levels. For the palatability assays and bryostatin analyses, the volume of each sample was determined by measuring its displacement of water in a $10 \mathrm{ml}$ graduated cylinder. The branches were cut into small pieces, placed into methanol for preservation and stored at $-20^{\circ} \mathrm{C}$. Previous research found that the bryostatins are contained in the lipophilic portion of the crude extract (Lopanik et al. 2004a). To make crude extracts for palatability tests, all $B$. neritina tissues were sequentially extracted once with methanol, 4 times with 1:1 mixture of dichloromethane and methanol, and then once more with methanol (all solvent volumes were $>10$ times the volume of tissue extracted). For each sample, these extracts were combined and evaporated to dryness by rotary evaporation. Each extract was then dissolved in 
a volume of methanol equal to the volume of tissue from which the extract was obtained.

Palatability assays with the crude extracts of all the Bugula neritina tissues were performed with the pinfish Lagodon rhomboides, which were housed and handled according to approved university IACUC protocols. Groups of 30 to 40 fish were maintained in separate containers for feeding assays. No more than 6 assays were run per day; some fish were assayed more than once per day. However, the fish were almost always willing to feed. Fish were maintained on a diet of frozen brine shrimp and fed to satiation twice each day. On days when assays were performed, fish were fed a small amount of food $\sim 2 \mathrm{~h}$ before the assays to ensure they were not starved. Small pellets of the assay food were prepared by mixing an amount of crude extract (after allowing the solvent to evaporate) from a given volume of larval or adult tissue into the same volume of a palatable squid-based food (see Lindquist \& Hay 1995 for the recipe). The feeding assays began by offering each individual fish ( $\mathrm{n}=12$ to 16) a small ( 2 to $3 \mathrm{~mm}$ diameter) pellet of the squidbased food without added extract (= control). If eaten, each fish then received an identical food pellet, except that it contained bryozoan tissue extract at the appropriate volumetric concentration. Virtually all fish took the treatment pellet into their mouths. After the treatment pellet was either eaten or rejected, each fish was offered a second control pellet to ensure that rejection of the treatment pellet was not due to satiation. Fish response to control and treatment pellets was recorded as accepted if the pellet was consumed and rejected if the fish expelled the pellet after taking it into its mouth. Only results from replicates for which both control pellets were consumed and the treatment pellet was taken into the mouth of the fish were included in statistical analyses.

Individual feeding assays with extracts of larval, juvenile, and ovicell-bearing and ovicell-free adult tissue extracts were analyzed with McNemar's test for significance of changes (Sokal \& Rohlf 1995). The palatabilities of the 3 individual adult ovicell-bearing and ovicell-free extract assays were compared using a 1-way ANOVA. Because of their small size, larvae and juveniles each had to be pooled in order to obtain enough material to conduct feeding assays with their extracts. To determine if there were significant differences between the palatability of larval and ovicellbearing and ovicell-free adult extracts, the result of the larval extract palatability assay was compared to the most unpalatable (i.e. most similar to the larval extract) of the 3 assays conducted with the extracts of individual ovicell-bearing and ovicell-free branches of adult colonies. These comparisons were made using pairwise Fisher's Exact Test with the appropriate adjust- ment of the test $\alpha$ value using the Bonferroni approach (Sokal \& Rohlf 1995). Differences in palatability among the larval and the juvenile stages were also determined using this method. Larval and juvenile crude extracts were compared by calculating differences between the palatability of the larval trial and the palatability of the most palatable juvenile extract, then the next most palatable extract, etc., until there was no significant difference. The $\alpha$ value was adjusted as above after each comparison using the Bonferroni adjustment (Sokal \& Rohlf 1995). The software SPSS 11.0 (Hearne Scientific Software) was used for statistical analyses.

Bryostatin concentrations in larval, juvenile, and adult tissue extracts were determined via analytical HPLC using a C18 column $(4.6 \times 250 \mathrm{~mm}$ Microsorb $5 \mu \mathrm{m}$ column, Varian), elution with a gradient of methanol and water, and photodiode array detection (Waters). Standard curves were generated with 5 known concentrations of the different bryostatins. Because the nutritional value of food items are often related to protein concentrations or total energy content, as well as to levels of structural materials that are not readily digestible (e.g. chitin) (reviewed by Cronin 2001), levels of soluble protein and structural material, represented in the case of Bugula neritina by chitin and calcium carbonate in the larval, juvenile, and adult stages were also determined per unit volume of tissue and statistically compared among the different life stages. These constituent materials were measured in 3 replicate samples of larval, juvenile (4 h, $1 \mathrm{~d}, 5 \mathrm{~d}$, and $7 \mathrm{~d}$ PS), and a mixture of ovicellbearing and ovicell-free adult tissues using the methods described by Harvey et al. (1997). Three aliquots of tissue from each life stage were used to determine their dry weight to volume ratios. The crude extract was removed as described previously, and the dry weight of the remaining tissue measured. The watersoluble extract was removed and the dry weight again measured. Mineral carbonates, including calcium carbonate which is found in B. neritina (Ryland 1970), were removed by acidifying the tissue with $1.5 \mathrm{~N} \mathrm{HCl}$, incubating at $45^{\circ} \mathrm{C}$ for $15 \mathrm{~min}$, and rinsing the remaining tissue with distilled water; the remaining tissue was dried and weighed and the mass of carbonate was calculated. Next, protein was solubilized by incubating the tissue in $3.5 \% \mathrm{NaOH}$ at $95^{\circ} \mathrm{C}$ for $20 \mathrm{~min}$. The remaining chitin was rinsed with $\mathrm{dH}_{2} \mathrm{O}$, dried, and weighed. To compare the amount of bryostatins versus tissue component, the mass of each component was divided by the total volume of tissue. The total volume of tissue was calculated by multiplying the dry weight by the average dry weight to volume ratio measured for the 3 replicate samples of the different life stages. 

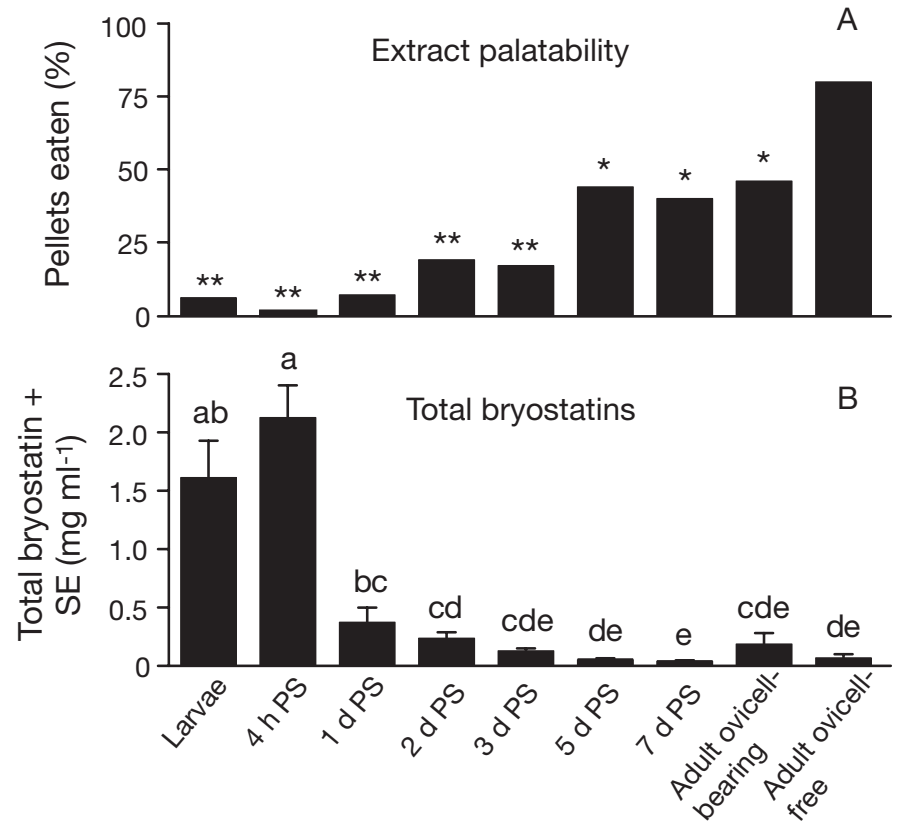

Fig. 1. Bugula neritina. Characteristics of life history stages. (A) Palatability of crude extracts to predator, Lagodon rhomboides ( $\mathrm{N}=14$ to 18 fish tested). For ovicell-bearing and ovicell-free adult crude extracts, data is shown for the least palatable (i.e. with palatability most similar to larvae) individual of the 3 colonies tested. Significance of difference from control (McNemar's test for significance of changes; ${ }^{*} \mathrm{p}<0.01$; $\left.{ }^{* *} \mathrm{p}<0.001\right)$. (B) Concentration of total bryostatins $\left(\mathrm{mg} \mathrm{ml}^{-1}\right)$ measured by analytical HPLC in volumetric extracts. Letters indicate significant differences in concentrations (1-way ANOVA, log transformed data, Tukey's HSD, $p<0.05)$. PS = post-settlement

\section{RESULTS}

\section{Palatability and bryostatin concentrations}

The larval and juvenile ( $4 \mathrm{~h}$ to $7 \mathrm{~d}$ PS) extracts of Bugula neritina significantly reduced pinfish feeding by 55 to $100 \%$ ( $<<0.01, \mathrm{n}=14$ to 18 , McNemar's test, Fig. 1A), and there was an apparent increase in palatability with increasing age of the post-settlement juveniles. The extract of ovicell-bearing branches of 3 adult $B$. neritina colonies also significantly reduced pinfish feeding $(-54 \%, \mathrm{p}=0.008, \mathrm{n}=13 ;-43 \%, \mathrm{p}=0.016, \mathrm{n}=$ $14 ;-40 \%, p=0.016, n=15 ;$ McNemar's test, Fig. 1A). In contrast, the extracts of branches lacking ovicells of the 3 adult colonies produced only a 12 to $20 \%$ decrease in fish feeding that was not significantly different from their consumption of the control food ( $\mathrm{p} \geq$ 0.125, $\mathrm{n}=13$ to 17, McNemar's test, Fig. 1A). The larval crude extract was significantly more unpalatable than both adult extracts and $7 \mathrm{~d}$ and $5 \mathrm{~d}$ PS juveniles ( $\mathrm{p}<$ 0.033, Fisher's Exact Test, 1 -sided $\left.\alpha^{\prime}=0.05\right)$. However, the palatability of the larval extract was not significantly different from the next most palatable extract, the $2 \mathrm{~d}$ old juvenile $(\mathrm{p}=0.3$, Fisher's Exact Test, 1 -sided $\left.\alpha^{\prime}=0.03\right)$. Further, when we compared the palatability of extracts from ovicell-bearing and ovicell-free branches within colonies of $B$. neritina, extracts from ovicell-bearing branches (avg. 54\% of food pellets consumed) were significantly more unpalatable ( $\mathrm{p}=$ 0.003, $\mathrm{n}=3$, blocked 1-way ANOVA) than the extract of ovicell-free branches (avg. $84 \%$ of pellets consumed).

HPLC analysis of the crude extracts revealed that the larval extract of Bugula neritina had high bryostatin concentrations, while adult ovicell-bearing and ovicell-free tissue extracts had bryostatin concentrations barely detectable by HPLC (Fig. 1B). Using analytical HPLC of larval extract, 4 bryostatins were identified based on their retention time and UV spectra (Lopanik et al. 2004a,b): bryostatins 10 and 20, and peaks D and G, 2 compounds that have been tentatively identified as bryostatins by their NMR and mass spectral characteristics. Concentrations of detected bryostatins were all substantially greater in larval extract than either ovicell-bearing or ovicell-free adult extracts. For example, bryostatin 10 levels were 78.4 and $91.5 \%$ lower in ovicell-bearing and ovicell-free adult colony extracts, respectively $(\mathrm{p}=0.041$ and 0.001 , respectively; logtransformed data, 1-way ANOVA, Tukey's HSD, Fig. 2A), compared to levels in larval tissue extract. There was no significant difference between bryostatin 10 levels in ovicell-bearing and ovicell-free tissue extracts $(p=0.441)$.

Similar to the decrease in deterrence with increasing juvenile age, there was also a decrease in the concentrations of the bryostatins in juvenile tissue extracts, which exhibited a sharp decline after $1 \mathrm{~d}$ of post-settlement growth (Fig. 2). The larval and $4 \mathrm{~h}$ PS juvenile extract concentrations of bryostatin 10 were significantly higher than all juvenile stages ( $p<0.040$ for all, 1-way ANOVA, Tukey's HSD, Fig. 2A). The $1 \mathrm{~d}$ and $2 \mathrm{~d}$ PS juvenile extracts had higher concentrations of bryostatin 10 than the $5 \mathrm{~d}$ and $7 \mathrm{~d}$ PS juvenile extracts $(\mathrm{p}<$ 0.015 for all, 1-way ANOVA, Tukey's HSD, Fig. 2A). Levels of bryostatin 20 and peak D in juveniles older than $1 \mathrm{~d}$ and adult colony extracts were below HPLC detection levels. Bryostatin 20 and peak D were significantly lower in $1 \mathrm{~d}$ PS juvenile extracts than in $4 \mathrm{~h}$ PS juvenile extracts $(p=0.006$ and 0.035 , respectively, 1-way ANOVA, Fig. 2B,C). Concentrations in larval extract were not different from either $4 \mathrm{~h}$ or $1 \mathrm{~d}$ PS juvenile extracts (Fig. 2B,C). For peak $G$, the larval extract concentration was not significantly different than levels in the $4 \mathrm{~h}, 1 \mathrm{~d}, 2 \mathrm{~d}$, and $3 \mathrm{~d}$ PS juvenile extracts (Fig. 2D). The concentration of peak $\mathrm{G}$ in $5 \mathrm{~d}$ PS juvenile extract was significantly lower than the levels in larval, $4 \mathrm{~h}, 1 \mathrm{~d}$, and $2 \mathrm{~d}$ PS juvenile extracts ( $p<0.015$ for all). 


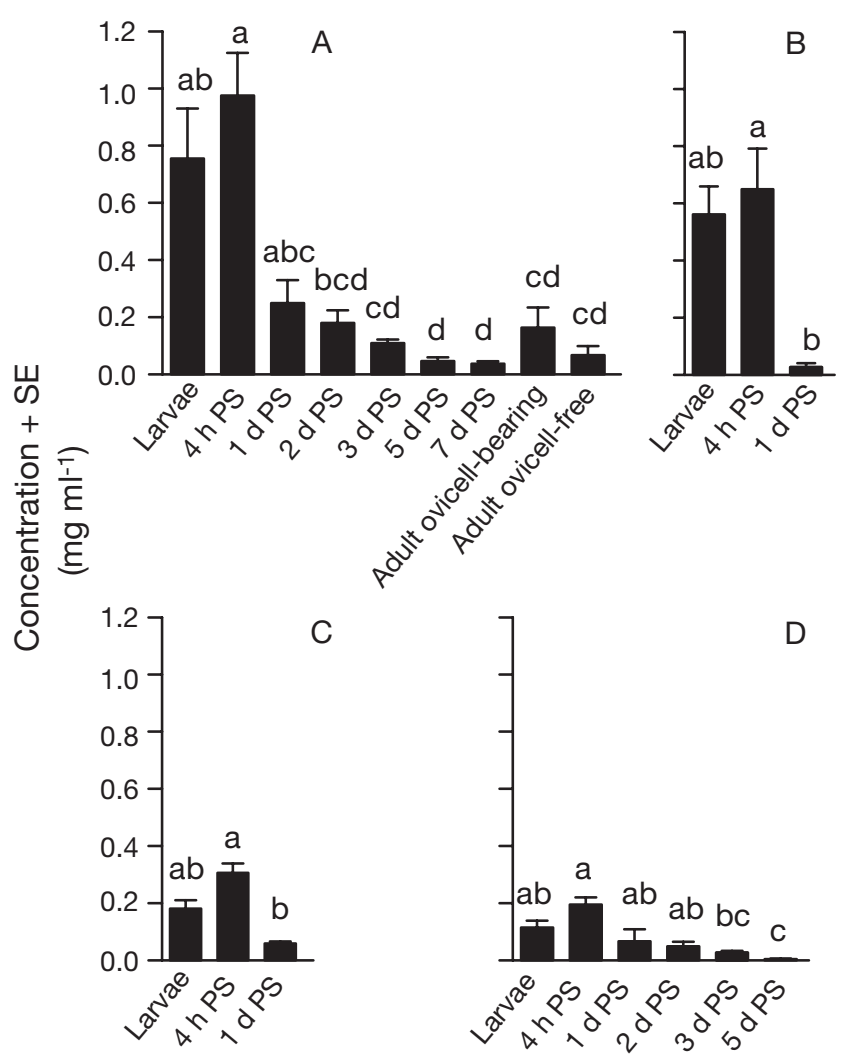

Fig. 2. Concentration (mg ml $\mathrm{m}^{-1}$ ) of (A) bryostatin 10, (B) bryostatin 20, (C) peak D, and (D) peak G in larval, juvenile and adult volumetric extracts. Letters indicate significant differences in concentrations (1-way ANOVA, log transformed data, Tukey's HSD, $\mathrm{p}<0.05)$. PS = post-settlement

\section{Total bryostatin and tissue component comparisons}

Bugula neritina larval and 4 h PS juvenile extracts had a significantly higher concentration of total bryostatins than juveniles $2 \mathrm{~d}$ and older, and than adult extracts, both ovicell-bearing and ovicell-free ( $\mathrm{p}<$ 0.016, 1-way ANOVA, log-transformed data, Fig. 1B). Larvae had a significantly higher amount of soluble protein than juvenile and adult tissue $(p<0.002$, 1 way ANOVA, log transformed data, Fig. 3A). While protein levels in $1 \mathrm{~d}$ and $5 \mathrm{~d}$ PS juveniles were lower than the larvae and $4 \mathrm{~h}$ PS juveniles, $7 \mathrm{~d}$ PS juvenile and adult protein levels were higher than in the younger juveniles (Fig. 3A). Larvae had a significantly lower amount of structural material than all of the other life stages ( $p<0.001,1$-way ANOVA, Fig. 3B); $4 \mathrm{~h}, 1 \mathrm{~d}$, and $5 \mathrm{~d}$ PS juveniles all had more than twice the amount of structural material than larvae. Adult mixed tissue had significantly more structural material than all the other life stages $(p<0.001,1$-way ANOVA).

\section{DISCUSSION}

Many adult sessile marine organisms employ a number of defensive strategies to ward off predators and competitors, including chemical, structural, and nutritional defenses (reviewed in Cronin 2001). Deterrent natural products have been shown to deter potential predators of a number of marine invertebrates (reviewed in Pawlik 1993). However, for those organisms lacking an effective chemical defense, alternative strategies such as structural features and low nutritional quality may reduce consumption by predators. For instance, structural features such as spicules, sclerites, or hard exoskeletons may aid to deter predators even though they are not specifically defensive features (Harvell et al. 1988, Harvell \& Fenical 1989, Hay et al. 1994, Schupp \& Paul 1994, O'Neal \& Pawlik 2002, Burns \& Ilan 2003). These characters can reduce the palatability of sessile marine organisms that do not appear to be chemically defended. Furthermore, those marine invertebrates that are clonal can regenerate, and therefore may be able to survive bouts of partial predation (Jackson 1985). As a result, the evolutionary pressure for the development of a chemical defense in some adult organisms may not be strong. While the parent may be clonal and able to survive partial predation, the larvae are functionally solitary and any predation would be lethal. In addition, the brooded larvae of

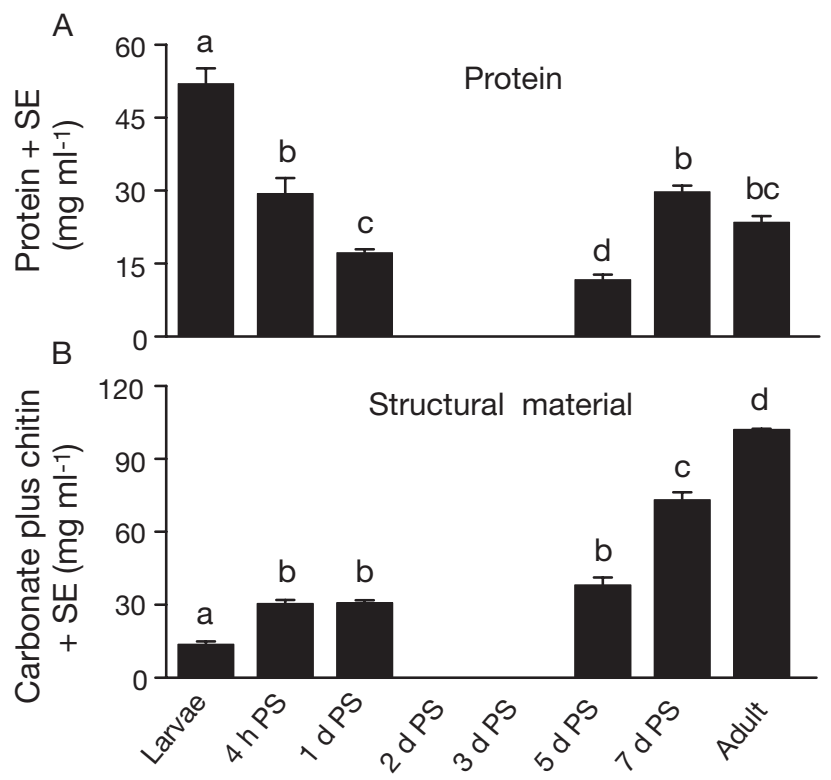

Fig. 3. Bugula neritina. Characteristics of life history stages. (A) Protein levels $\left(\mathrm{mg} \mathrm{ml}^{-1}\right.$ ). (B) Levels of structural material, in the form of carbonate plus chitin $\left(\mathrm{mg} \mathrm{ml}^{-1}\right)$. Levels of protein and structural material were not measured in $2 \mathrm{~d}$ or 3 d PS juveniles. Letters indicate significant differences in concentrations (1-way ANOVA, Tukey's HSD, p < 0.05). PS $=$ post-settlement 
many marine invertebrates typically remain near the benthos after spawning, are large and soft bodied, and have greater nutrient reserves compared to their planktotrophic counterparts, making them potentially highly desirable prey for a great number of small fishes and benthic particle feeders. Therefore, evolutionary pressure for the production of a chemical defense should be high, and, in fact, many brooded larvae are unpalatable to multiple predator types (Lindquist 1996, Lindquist \& Hay 1996, Lindquist 2002). Like their larvae, the post-settlement juveniles of many sessile invertebrates are typically small in size such that even moderate amounts of physical damage can be catastrophic. Because post-settlement mortality is typically very high (Hunt \& Scheibling 1997), resulting from both biotic (e.g. predation) and abiotic (e.g. UV exposure) factors (Gosselin \& Qian 1997), it can be a major factor influencing the structure of many marine communities (Keough \& Downes 1982, Osman et al. 1992, Osman \& Whitlatch 1995, Gosselin \& Qian 1997). Traits that reduce the amount of mortality at these stages are likely to be propagated in the next generations.

The life history of the bryozoan Bugula neritina consists of a colonial adult that releases brooded larvae. Larvae are released during the mid-morning hours and are therefore very apparent and should be vulnerable to predators. The larvae appear to be more nutritious, and are soft-bodied (as indicated by the lower amount of structural material) compared to the adults (Fig. 3A,B), making them potentially very desirable prey. However, high concentrations of bryostatins render the larvae unpalatable, thereby chemically defending them from potential predators (Lopanik et al. 2004a). Larvae typically settle within $2 \mathrm{~h}$ of release in the presence of a suitable substratum (Keough 1989), and then immediately begin metamorphosis into the ancestrula stage (i.e. the first zooid stage) (Woollacott \& Zimmer 1971). While bryostatin concentrations significantly decrease after settlement (Figs. 1B \& 2), the palatability data indicate that the bryostatin concentrations in these stages are sufficient to deter predation (Fig. 1A). As juvenile age increases, the amount of structural material in the form of carbonate and chitin increases (Fig. 3B), suggesting that the later developmental stages rely on physical defense and lower nutritional value to reduce their attractiveness to predators. Although predation is one of many factors that can result in high mortality rates for newly settled marine invertebrates (Gosselin \& Qian 1997, Hunt \& Scheibling 1997), the ability of larvae to selectively settle on topographically complex substrata that can provide refuge from the mouthparts of large predators may be more ecologically important than the chemical defense. In fact, $B$. neritina larvae preferentially settle on complex substrata that may offer small- and medium-scale refuge from predators, competitors, physical disturbance, or UV radiation (Walters 1992a,b, Walters \& Wethey 1991, 1996). This settlement behavior probably results in reduced post-settlement mortality, and thus less of a dependence on a chemical defense at the early juvenile stages. While juvenile $B$. neritina are unpalatable to at least one potential predator (i.e. Lagodon rhomboides), the simultaneous increase in palatability and reduction in bryostatin concentration supports the hypothesis that juvenile and adult $B$. neritina relies less on chemical defense, which appears to be the only defensive strategy at the larval stage. Ontogenetic changes in defense, both morphological and chemical, have been demonstrated in other marine invertebrates (Lowell et al. 1994, Cowart et al. 2002), and may be a mechanism to reduce the cost of defense when it is not needed.

Adult Bugula neritina are significantly more palatable (Fig. 1A), and have much lower concentrations of bryostatins than larvae (Figs. 1B \& 2A). Lim \& Haygood (2004) showed that California populations of B. neritina larvae have higher levels of bryostatins than adults, similar to the North Carolina populations in this study. The patterns of larval and adult extract palatabilities (Fig. 1A) suggest that the lower palatability of ovicell-bearing adult tissue (versus ovicell-free adult tissue) may be due to the presence of brooded larvae, which have high concentrations of bryostatins. Higher levels of chitin and carbonate may increase the toughness of late juvenile and adult $B$. neritina branches, thereby reducing attractiveness as prey. Moreover, calcium carbonate has been shown to reduce feeding by some, but not all, herbivorous fishes (Hay et al. 1994, Schupp \& Paul 1994), perhaps by altering gut $\mathrm{pH}$, which may reduce the efficiency of digestion enzymes. While the presence of carbonate and possibly other minerals, as well as chitin, may not deter predators individually, there is the potential for them to be deterrent in concert (Hay et al. 1994), and very low concentrations of bryostatins may synergistically enhance their effects. The lower nutritional value of late juveniles and adults as reflected by the lower amount of protein (Fig. 3A) may also contribute to their defense, although the values exceed the threshold for a reduced feeding response for pinfish as reported in Bullard \& Hay $\left(2002 ; 11.7 \mathrm{mg} \mathrm{m}^{-1}\right.$ in 5 d juveniles versus $<1.5 \mathrm{mg} \mathrm{ml}^{-1}$ to reduce feeding in pinfish).

The model predator used in these studies, Lagodon rhomboides, is a generalist omnivore that co-occurs with Bugula neritina at all life stages along the Southeast US coast (Hay \& Sutherland 1988). B. neritina larvae, which lack physical or behavioral means to avoid predation (Lindquist \& Hay 1996), are rejected as prey by particle- and filter-feeding invertebrates (Lindquist 1996, Tamburri \& Zimmerfaust 1996), as well as by fishes (Lindquist \& Hay 1996), suggesting that they are defended by noxious chemicals that are broadly effec- 
tive against diverse taxa of potential predators (Lindquist \& Hay 1996, Lopanik et al. 2004a). These studies demonstrate that fish and invertebrates will attack $B$. neritina larvae when encountered, but that predators reject the larvae, which, even after these attacks, typically survive to settle and metamorphose (Lindquist 1996, Lindquist \& Hay 1996). Although L. rhomboides can readily learn to avoid chemically unpalatable prey, even if the prey is small and rare (Lindquist \& Hay 1995), juvenile fish recruiting to coastal habitats where $B$. neritina is common probably select for the maintenance of the defensive symbiosis between B. neritina and Candidatus Endobugula sertula. Lessening of the defensive symbiosis would result in increased predation on B. neritina larvae, thereby exerting selection to maintain the symbiosis.

The difference in deterrent bryostatin concentrations between adult and larval Bugula neritina may be directly related to the different selective forces that each of these life stages face because of their different morphologies (large versus small; presence versus relative absence of structural material) and habitat (exposed on the benthos versus exposed but free-living above the benthos), all of which affects their relative susceptibility to predation. Further, selection imposed by predators appears to be one of the evolutionary forces leading to the maintenance of the B. neritina-Candidatus Endobugula sertula symbiosis, through which the symbiont provides a powerful chemical defense for the protection of its host's larvae, but not likely the other life stages of the host.

Acknowledgements. We thank J. Weisz, C. Jones, and G. Safrit for assistance with collections of B. neritina. Sigma Xi Grants in Aid of Research to N.B.L. and SG project R/F-9 to N.M.T. funded portions of this project. We also thank 3 anonymous reviewers for comments that substantially improved this manuscript.

\section{LITERATURE CITED}

Adams SM (1976) Feeding ecology of eelgrass fish communities. Trans Am Fish Soc 105:514-519

Amsler CD, McClintock JB, Baker BJ (2001) Secondary metabolites as mediators of trophic interactions among Antarctic marine organisms. Am Zool 41:17-26

Bullard SG, Hay ME (2002) Palatability of marine macro-holoplankton: nematocysts, nutritional quality, and chemistry as defenses against consumers. Limnol Oceanogr 47: 1456-1467

Burns E, Ilan M (2003) Comparison of anti-predatory defenses of Red Sea and Caribbean sponges. II. Physical defense. Mar Ecol Prog Ser 252:115-123

Cowart JD, Fielman KT, Woodin SA, Lincoln DE (2000) Halogenated metabolites in two marine polychaetes and their planktotrophic and lecithotrophic larvae. Mar Biol 136: 993-1002
Cronin G (2001) Resource allocation in seaweeds and marine invertebrates: chemical defense patterns in relation to defense theories. In: McClintock JB, Baker BJ (eds) Marine chemical ecology. CRC Press, New York, p 325-353

Darcy GH (1985) Synopsis of biological data on the pinfish Lagodon rhomboides (Pisces: Sparidae), National Oceanic and Atmospheric Administration Technical Report. NMFS 23

Davidson SK, Allen SW, Lim GE, Anderson CM, Haygood MG (2001) Evidence for the biosynthesis of bryostatins by the bacterial symbiont 'Candidatus Endobugula sertula' of the bryozoan Bugula neritina. Appl Environ Microbiol 67:4531-4537

Davis AR (1989) Contrasting population dynamics and life histories in two populations of the colonial subtidal ascidian Podoclavella moluccensis. Mar Ecol Prog Ser 51: 107-119

Duffy JE, Paul VJ (1992) Prey nutritional quality and the effectiveness of chemical defenses against tropical reef fishes. Oecologia 90:333-339

Engel S, Jensen PR, Fenical W (2002) Chemical ecology of marine microbial defense. J Chem Ecol 28:1971-1985

Gil-Turnes MS, Fenical W (1992) Embryos of Homarus americanus are protected by epibiotic bacteria. Biol Bull 182: 105-108

Gil-Turnes MS, Hay ME, Fenical W (1989) Symbiotic marine bacteria chemically defend crustacean embryos from a pathogenic fungus. Science 246:116-118

Gosselin LA, Qian PY (1997) Juvenile mortality in benthic marine invertebrates. Mar Ecol Prog Ser 146:265-282

Harvell CD, Fenical W (1989) Chemical and structural defenses of Caribbean gorgonians (Pseudopterogorgia spp.): intracolony localization of defense. Limnol Oceanogr 34:382-389

Harvell CD, Fenical W, Greene CH (1988) Chemical and structural defenses of Caribbean gorgonians (Pseudopterogorgia spp.). I. Development of an in situ feeding assay. Mar Ecol Prog Ser 49:287-294

Harvell CD, West JM, Griggs C (1996) Chemical defense of embryos and larvae of a West Indian gorgonian coral, Briareum asbestinum. Invertebr Reprod Dev 30:239-246

Harvey M, Bourget E, Gagne N (1997) Spat settlement of the giant scallop, Placopecten magellanicus (Gmelin, 1791), and other bivalve species on artificial filamentous collectors coated with chitinous material. Aquaculture 148: $277-298$

Hay ME (1996) Marine chemical ecology: What's known and what's next? J Exp Mar Biol Ecol 200:103-134

Hay ME, Sutherland JP (1988) The ecology of rubble structures of the South Atlantic Bight: a community profile. Biological Report 85(7.20), United States Fish and Wildlife Service, Department of the Interior, Washington, DC

Hay ME, Kappel QE, Fenical W (1994) Synergisms in plant defenses against herbivores: interactions of chemistry, calcification, and plant quality. Ecology 75:1714-1726

Haygood MG, Davidson SK (1997) Small-subunit rRNA genes and in situ hybridization with oligonucleotides specific for the bacterial symbionts in the larvae of the bryozoan Bugula neritina and proposal of 'Candidatus Endobugula sertula'. Appl Environ Microbiol 63:4612-4616

Haygood MG, Schmidt EW, Davidson SK, Faulkner DJ (1999) Microbial symbionts of marine invertebrates: Opportunities for microbial biotechnology. J Mol Microbiol Biotechnol 1:33-43

Heck KL Jr, Pennock JR, Valentine JF, Coen LD, Sklenar SA (2000) Effects of nutrient enrichment and small predator 
density on seagrass ecosystems: an experimental assessment. Limnol Oceanogr 45:1041-1057

Hunt HL, Scheibling RE (1997) Role of early post-settlement mortality in recruitment of benthic marine invertebrates. Mar Ecol Prog Ser 155:269-301

Iyengar EV, Harvell CD (2001) Predator deterrence of early developmental stages of temperate lecithotrophic asteroids and holothuroids. J Exp Mar Biol Ecol 264:171-188

Jackson JBC (1985) Distribution and ecology of clonal and aclonal benthic invertebrates. In: Jackson JBC, Buss LW, Cook RE (eds) Population biology and evolution of clonal organisms. Yale University Press, New Haven, CT p 297-355

Keough MJ (1989) Dispersal of the bryozoan Bugula neritina and effects of adults on newly metamorphosed juveniles. Mar Ecol Prog Ser 57:163-171

Keough MJ, Downes BJ (1982) Recruitment of marine invertebrates: the role of active larval choices and early mortality. Oecologia 54:348-352

Kobayashi J, Ishibashi M (1993) Bioactive metabolites of symbiotic marine microorganisms. Chem Rev 93:1753-1769

Lim GE, Haygood MG (2004) 'Candidatus Endobugula glebosa,' a specific bacterial symbiont of the marine bryozoan Bugula simplex. Appl Environ Microbiol 70:4921-4929

Lindquist N (1996) Palatability of invertebrate larvae to corals and sea anemones. Mar Biol 126:745-755

Lindquist N (2002) Chemical defense of early life stages of benthic marine invertebrates. J Chem Ecol 28:1987-2000

Lindquist N, Hay ME (1995) Can small rare prey be chemically defended? The case for marine larvae. Ecology 76 : 1347-1358

Lindquist N, Hay ME (1996) Palatability and chemical defense of marine invertebrate larvae. Ecol Monogr 66: 431-450

Lindquist N, Hay ME, Fenical W (1992) Defense of ascidians and their conspicuous larvae: Adult vs. larval chemical defenses. Ecol Monogr 62:547-568

Lindquist N, Barber PH, Weisz JB (2005) Episymbiotic microbes as food and defence for marine isopods: unique symbioses in a hostile environment. Proc R Soc Ser B 272: $1209-1216$

Lopanik N, Lindquist N, Targett N (2004a) Potent cytotoxins produced by a microbial symbiont protect host larvae from predation. Oecologia 139:131-139

Lopanik N, Gustafson KR, Lindquist N (2004b) Structure of bryostatin 20: a symbiont-produced chemical defense for larvae of the host bryozoan, Bugula neritina. J Nat Prod 67:1412-1414

Lowell RB, Fletcher CR, Grahame J, Mill PJ (1994) Ontogeny of shell morphology and shell strength of the marine snails Littorina obtusata and Littorina mariae: different defence strategies in a pair of sympatric, sibling species. J Zool 234:149-164

McClintock JB, Baker BJ (2001) Marine chemical ecology. CRC Press, Boca Raton, FL

McDougall KD (1943) Sessile marine invertebrates of Beaufort, North Carolina: A study of settlement, growth and seasonal fluctuations among pile-dwelling organisms. Ecol Monogr 13:322-374

Nelson WG (1979) Experimental studies of selective predation on amphipods: consequences for amphipod distribution and abundance. J Exp Mar Biol Ecol 38:225-245

O'Neal W, Pawlik JR (2002) A reappraisal of the chemical and physical defenses of Caribbean gorgonian corals against predatory fishes. Mar Ecol Prog Ser 240:117-126

Osman RW, Whitlatch RB (1995) Predation on early ontogenic life stages and its effect on recruitment into a marine epifaunal community. Mar Ecol Prog Ser 117:111-126

Osman RW, Whitlatch RB, Malatesta RJ (1992) Potential role of micropredators in determining recruitment into a marine community. Mar Ecol Prog Ser 83:35-43

Pawlik JR (1993) Marine invertebrate chemical defenses. Chem Rev 93:1911-1922

Pettit GR (1996) Progress in the discovery of biosynthetic anticancer drugs. J Nat Prod 59:812-821

Piel J (2004) Metabolites from symbiotic bacteria. Nat Prod Rep 21:519-538

Ryland JS (1970) Bryozoans. Hutchinson University Library, London

Schupp PJ, Paul VJ (1994) Calcium carbonate and secondary metabolites in tropical seaweeds: variable effects on herbivorous fishes. Ecology 75:1172-1185

Sokal RR, Rohlf FJ (1995) Biometry, 3rd edn. WH Freeman, New York

Tamburri MN, Zimmer-Faust RK (1996) Suspension feeding: basic mechanisms controlling recognition and ingestion of larvae. Limnol Oceanogr 41:1188-1197

Tarjuelo I, López-Legentil S, Codina M, Turon X (2002) Defence mechanisms of adults and larvae of colonial ascidians: patterns of palatability and toxicity. Mar Ecol Prog Ser 235:103-115

Uriz MJ, Turon X, Becerro MA, Galera J (1996) Feeding deterrence in sponges. The role of toxicity, physical defenses, energetic contents, and life-history stage. J Exp Mar Biol Ecol 205:187-204

Walters LJ (1992a) Field settlement locations on subtidal marine hard substrata: Is active larval exploration involved? Limnol Oceanogr 37:1101-1107

Walters LJ (1992b) Post-settlement success of the arborescent bryozoan Bugula neritina (L.): the importance of structural complexity. J Exp Mar Biol Ecol 164:55-71

Walters LJ, Wethey DS (1991) Settlement, refuges, and adult body form in colonial marine invertebrates: a field experiment. Biol Bull 180:112-118

Walters LJ, Wethey DS (1996) Settlement and early post-settlement survival of sessile marine invertebrates on topographically complex surfaces: the importance of refuge dimensions and adult morphology. Mar Ecol Prog Ser 137: 161-171

Woollacott RM (1981) Association of bacteria with bryozoan larvae. Mar Biol 65:155-158

Woollacott RM, Zimmer RL (1971) Attachment and metamorphosis of cheilo-ctenostome byozoan Bugula neritina (Linne). J Morphol 134:351-382

Woollacott RM, Zimmer RL (1975) A simplified placenta-like system for the transport of extraembryonic nutrients during embryogenesis of Bugula neritina (Bryozoa). J Morphol 147:355-378

Young CM, Bingham BL (1987) Chemical defense and aposematic coloration in larvae of the ascidian Ecteinascidia turbinata. Mar Biol 96:539-544

Young CM, Chia FS (1987) Abundance and distribution of pelagic larvae as influenced by predation, behavior and hydrographic factors. In: Giese AC, Pearse JS, Pearse VB (eds) Reproduction of marine invertebrates, Vol 9. Blackwell Scientific, Palo Alto, CA, p 385-463

Submitted: April 12, 2005; Accepted: March 30, 2006

Proofs received from author(s): October 26, 2006 